\title{
KDM7A Divergent Transcript
}

National Cancer Institute

\section{Source}

National Cancer Institute. KDM7A Divergent Transcript. NCI Thesaurus. Code C158445.

KDM7A divergent transcript ( 2 kb) is encoded by the human KDM7A-DT gene. The function of this long noncoding RNA is unknown. 